\section{What made our ancestors put the words together?}

\section{Emrullah Şeker ${ }^{1 *}$ ๑}

'Asst. Prof. Dr. | Bitlis Eren University, Faculty of Arts and Sciences, Department of Western Languages and Literature, Bitlis - Turkey
* Sorumlu Yazar / Corresponding Author: Emrullah Şeker Bitlis Eren Üniversitesi Fen Edebiyat Fakültesi Batı Dilleri ve Edebiyatları Bölümü İngiliz Dili ve Edebiyatı Anabilim Dalı Rahva Yerleşkesi Beş Minare Mahallesi Ahmet Eren Bulvarı 13000 Merkez, Bitlis/Türkiye E-mail: emrullahseker@yahoo.com

Alındı/Received: 25 Haziran / June 2020 | Düzeltildi/Revised: 7 Haziran / June 2021 | Kabul/Accepted: 15 Haziran / June 2021 |Yayımlandı/Published: 28 Haziran / June 2021

\begin{abstract}
This article introduces an evolutionary approach to the ontogeny of grammar and establishes a relation between sexual behaviors and mental linguistic mechanisms in phylogeny. Initially, it presents a summary of evolutionary ideas relating to language evolution and the nature of adaptations, and holistically discuss them in terms of sexual selection. Next, generative, hierarchical, gendered, combinatorial and recursive operations are illustrated, explained and discussed in order to unroll the ancestral linguistic characters in the ontogeny of grammar. Finally, the linguistic characters such as generation, symbolism, hierarchy, gender, merge and recursivity in the ontogeny are correlated with other reproductive, symbolic, sexual, combinatorial, hierarchical, iterative, repetitive, recursive experiences in ontogeny and phylogeny in order to identify what mental mechanisms in the phylogeny are recapitulated. The conclusion is that symbolic thought as the origin of several developments in human mental evolution as well as merge and recursivity characters of grammar in ontogeny is the side-effect of sexual pleasure from ventro-ventral sexual experience. In other words, ventro-ventral sex is introduced as the antecedent of symbolic thought and protolanguage. This grounding led to the postulation that generation, symbolism, hierarchy, gender, merge and recursivity in the ontogeny of grammar are regressions to earlier evolutionary stages of copulatory, particularly ventro-ventral, patterns in the phylogeny.
\end{abstract}

Key words: Protogrammar, ventro-ventral sex, merge, recursion evolution, symbolic thought

\section{Introduction}

As for thousands of years, in modern era, sexuality is still the main theme of literature, theater, cinema, art, entertainment and commercials which may point to "the origin of the shared ways of thinking, feeling, and behaving in human evolutionary history" (Kauth, 2007, p. 2-3). Of course, not only for such human activities but also for almost all known animal and plant species, sexuality is a primary concern, which demonstrates that "it dominates our planet" (Miller, 2001, p. 175176). Sex, sexuality, and sexual communication are inherently pervasive in human communication and a
Atalarımızın sözcükleri birleştirmesine neden olan şey ne idi?

$\ddot{O} z$

Bu makale dilbilgisi ontojenezine evrimsel bir yaklassm getirmekte ve soyolusta cinsel davranıslar ile zibinsel dilsel mekanizmalar arasinda bir ilișki kurmaktader. Çalısmada, ilk olarak, dil evrimi ve adaptasyonlarn doğast ile ilgili evrimsel görïslerin bir özeti sunuldmus ve ardindan bunlar cinsel seçilim açısindan bütüncül bir şekilde tartışlmuştır. Daba sonra, dilbilgisinin ontojenęৃinde eski çă̆lardan beri bulunduğgu düsünülen atasal dilsel öz̨ellikleri açılamak için üretken, biyerarşik, cinsiyetli, birleşimli ve yinelemeli yapular tartısılmuștır. Son olarak, filojenezde hangi zibinsel mekanižmalarm tekrarlandiğm belirlemek için üretkenlik, sembolizm, biyerarşi, cinsiyet, birleşim ve yineleme gibi dilbilgisel özellikler ontojenezde ve filojenezde diğer üreyici, biyerarşik, cinsel, birleșimli ve yinelemeli deneyimlerle ilișkilendirilmiştir. Sonuc olarak, insanm zi ihinsel ve dilsel evrimindeki çesitti gelismelerin kaynăğ olan sembolik düsünce dilbilgisel ontojenezde yüz yüre cinsel deneyimle elde edilen cinsel

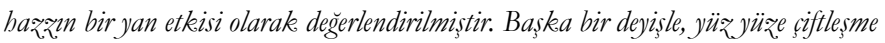
sembolik düsüncenin ve dilin öncülü olarak gösterilmistir. Buradan yola çıkarak dilbilgisi yapular ontojenezindeki üretkenlik, semboližm, hiyerarși, cinsiyet, birleşim ve yinelemenin filojenezde dilbilgisinin çiftleșme kahplarnm, özellikle de yür yüze ciftleșme deneyiminin, daha önceki evrimsel aşamalarna gerileme olduğu sonucuna varilmıștir.

Anahtar sözcükler: Protogramer, yǚ yüze siftlesme, birleștirme, yineleme, evrim, sembolik dïsïnce

wide variety of engagements (see Tooby and Cosmides, 1992; Taylor, 1996; Kauth, 2007). This pervasion makes perfect sense to explain many human creative affairs and perhaps even the evolution of bigger brains (Dawkins, 1976; Gould, 1987; Miller, 2001). Darwin's (1871) suggestion that human mental evolution owes much to sexual selection through mate choice is the principle theory which has been referred to explain creative aspects of human behavior such as language, art, music, technical productions and inventions. Most of them are regarded too luxurious and costly in terms of survival interests as in the case of peacock's tail 
(e.g. Campbell, 1974; Barkow et al., 1992; Miller, 2001). This assertion has paved the way for the successive studies to attempt to speculate about protolanguage, or primitive origins of language, through more robust hypotheses (e.g. Chomsky, 1991; Wray, 1998; Arbib, 2012; Zywiczynski et al., 2017). However, when it comes to the underlying drives leading to protogrammar, there seems to be a gap (see also Pinker and Bloom, 1990). In order to fill this gap, evolutionary explanations refer to a sudden cognitive mutation like a big bang, or like a gift by an omniscient deity, or a gradual mutation or the emergence of protogrammar (e.g. Pinker, 2003; Bickerton and Szathmáry, 2009).

Although studying hierarchical and recursive structures in language is subject of contemporary synchronic linguistics, researching or speculating on linguistic changes with time is a diachronic approach. Considering the origin and evolution of the underlying linguistic mechanisms of these structures, in addition, studying hierarchy and recursion in language not only falls within the domain of anthropologists, paleontologists, archaeologists, psychologists but also linguists as well. In this study, based on the data obtained from the disciplines mentioned in the previous lines, I try to correlate certain combinatorial ancestral characters such as hierarchy, gender, merge and recursion in the ontogeny of grammar with the copular, iterative and repetitive experience of sex, sexual behavior, sexual pleasure and symbolic thought in ontogeny and phylogeny. The arguments on the role of sex, sexuality and sexual behavior in the evolutionary emergence of protolanguage are asserted by various scholars (e.g. Dawkins, 1976; Tooby and Cosmides, 1992; Taylor, 1996; Garza-Mercer, 2007; Kauth, 2007; Tallerman, 2014). These arguments seem plausible and explanatory enough to speculate on the underlying mechanisms responsible for protogrammar. Sex for reproductive concerns is at the heart of life not only for human but also for other species (Launer, 2014). In contrast, nonreproductive sex for sexual pleasure is also dominant particularly among humans and the closest extant human relatives such as bonobos or Japanese macaques (see Manson and Parish, 1997; Hull et al., 2002; King, 2004, Sommer and Vasey, 2006; Balcombe, 2009 for primate sexual behaviors). According to psychologist Garza-Mercer (2007), sufficient frequency in sexual pleasure drives human behavior. Within this view, it is unlikely to ignore that human mind and human behavior have been affected by the human specific ventro-ventral, or face-to-face, copulation technique experienced and reinforced by sexual pleasure for millions of years probably after bipedalism evolved among hominids. This iterative experience of sexual pleasure may have been the trigger for several human particular features and abilities including the development of large brain, creativity, tool-making and, in particular, symbolic thought and language (see McHenry, 1994; Lovejoy, 1988; Manson et al., 1997; King, 2004, Gallup, 2015). That is the most significant argument on which the correlations and scenarios are established in this study since certain ancestral characters in the ontogeny could be regressions to earlier evolutionary stages in the phylogeny (Haeckel, 1866 as cited in Gilbert, 2006).

The term protolanguage has been used by many scholars (e.g. Bickerton, 1990; Pinker and Bloom, 1990; Greenfield, 1991; Johansson, 2006; Hurford, 2007; Arbib, 2012; Zywiczynski et al., 2017). It has been discussed on holistic and structural bases, on which either its original manipulative utility purposes (e.g. Dunbar, 1996; Wray, 1998; Miller, 2001; Pinker, 2003; Arbib, 2012) or its combinatorial synthetic system (e.g. Bickerton, 1990; Tallerman, 2008) has been speculated. While the term protolanguage chimes in with the former approach, the term protogrammar (see Greenfield, 1991; Johansson, 2006) befits the latter one. On holistic base, Pinker (2003) simulates protolanguage as the one to which children, pidgin speakers, immigrants, tourists, aphasics, slang users, telegrams, or headlines resort under natural selection pressures. On structural base, on the other hand, Bickerton (2002) uses protogrammar for the same contexts in order to conclude the structure of the protolanguage that homo erectus spoke. He, finally, suggests a bottom-up protogrammar with proto-concepts such as nouns and verbs being the basic units from which other linguistic categories are derived (Bickerton, 1990). However, Tallerman (2008) favors structural approach in that it is more credible and workable model for early hominid communication. In this paper, while sexual selection is undertaken as the holistic approach to explain sexually woven mating mind, the ontogeny and phylogeny of protogrammar is discussed on structural basis.

The main purpose of this paper is, therefore, to present an evolutionary structural approach to the ontogeny of grammar and to find out the relation between sexual behaviors and protogrammar in the phylogeny. In this article, I first introduce a summary of evolutionary ideas relating to language evolution and the nature of adaptations, and holistically discuss them in terms of sexual selection in order to demonstrate that sex and language are interrelated. Second, combinatorial patterns such as reproduction, hierarchy, iteration, repetition, sexual relations, and gender in the phylogeny of copulation and the relation between symbolic thought and sexual behaviors are discussed in order to set forth the combinatorial characteristics in the phylogeny. Next, the nature of hierarchical phrase structure, gender, merge and recursion are discussed in 
order to unroll the ancestral linguistic characteristics in the ontogeny of grammar. Finally, the linguistic characters such as generation, symbolism, hierarchy, gender, merge and recursivity are correlated with other symbolic, combinatorial, hierarchical, sexual, gendered, recursive and iterative experiences in ontogeny and phylogeny in order to identify what mental mechanisms in the phylogeny are recapitulated.

\section{Language and sex in evolution}

The common characteristics observed between creative aspects of human behavior and sexual traits have been inspirers for various scientists to link these creative mechanisms to the sexual selection pressures (e.g. Andersson, 1994; Miller, 2001; Pinker, 2003). In concert with this literature, the studies on the speculations about the origin of language have largely focused on cognitive developments in terms of natural selection, sexual selection or psychoanalysis based on archaic and modern human linguistic or behavioral data, comparative primate studies and biological or archaeological evidence (e.g. Pinker and Bloom, 1990; Barkow, Cosmides and Tooby, 1992; Dunbar, 1996; Miller, 2001; Hurford, 2003; Pinker, 2003; Johansson, 2006; Tallerman, 2008, 2011; Wacewicz and Zywiczynski, 2012). In some of these studies, language is undertaken as an instinctive behavior evolved through natural selection just like the spiders' web-spinning (Pinker, 2003, p. 36). In others, language like art and music is a courtship adaptation, or an ornamentation, and a problem solving mechanism evolved through sexual selection (e.g. Darwin, 1871; Barkow et al., 1992; Buss, 1994; Miller, 2001; Kauth, 2007; Launer, 2014). In some others, it evolved as a result of abstract and symbolic thought (e.g. Freud, 1916 as cited in Strachey, 1963; Forrester, 1980; Pfeiffer, 1982; Bickerton, 1990; d'Errico and Vanhaeren, 2009; Tallerman, 2014; Tattersall, 2014). Furthermore, in the various literature, language evolution is associated with increased human creative and cognitive capacity, a side effect of larger brain size, or social relationships (e.g. Gould, 1987; Greenfield, 1991; Dunbar, 1996; Calvin and Bickerton, 2001). Among the studies outlined above, the books by evolutionary psychologists like Jerome Barkow, Leda Cosmides, and John Tooby's (1992) The Adapted Mind: Evolutionary Psychology and the Generation of Culture and Geoffrey Miller's (2001) The Mating Mind: How Sexual Choice Shaped the Evolution of Human Nature are noteworthy references. In addition, David Buss's (1994) The Evolution of Desire: Strategies of Human Mating and Steven Pinker's (2003) The Language Instinct: How the Mind Creates Language are significant references in that they successfully bridge between evolution, sex and language through a multidisciplinary perspective.

Sexual selection, as one the main focus and approach of the aforementioned studies, is known as "the evolution of characteristics because of their reproductive benefits, rather than survival benefits" (Buss,1994, p. 3). In this respect, Darwin (1871) arrives at a conclusion that bodily ornaments such as extremities, sexual organs, breasts, buttocks, feathers, body hair, and lips of males in different species may have been equipped through female choice. While natural selection is heavily within the domain of disciplines such as biology, anthropology, and paleontology, sexual selection has crucial assertions on human behaviors within the domain of social sciences including language studies. "No social relationship remains untouched by mating." and in brief, "it defines who we are" (Buss,1994, p. 286). Preferences and competition for a mate or hunting for successful mating, or courtship, underlie many human activities including not only innovations such as art, music, technical productions and inventions but also ventures such as friendship, competition, motivation, murder, love, altruism etc. (see Darwin, 1871; Buss, 1994; Miller, 2001; Launer, 2014). The collection of sexual strategies has provided humans with exceptional advantages over other species, and thus they are still carried out despite tremendous changes in the social and environmental context (Buss, 1994). Geher and Miller (2008, p. 10) call those capacities evolved, learned, or invented for mating by the mind's reproductive system as mating intelligence. The more intelligent the hominids became, the more creative intelligence they demanded from their sexual partners, allowing creative intelligence to evolve as a pure sexual ornament rather than a survival adaptation (Miller, 2001, p. 73).

Creativity as an adaptive ornamentation like our minds is closely associated with novelty and utility, both of which correspond to the fundamental characteristics of courtship (see Miller, 2001; Geher and Miller, 2008; Kaufman, 2014). Tattersall (2014, p. 204) associates it with our ancestors' invention of language metaphorically portrayed as the ancestral birds' discovery of their feathers' already-existing potential to fly. Creativity can be paraphrased as "a restless appetite for change" (Tattersall, 2014, p. 204). This appetite for change in quest of novelty and utility can also be associated with the evolution of language since novelty is also a prominent characteristic of language and "it conveys news" (Pinker, 2003, p. 83; see also Bolinger, 1980 for utility within language). In addition, from a pragmatic survival point of view, language like other courtship ornaments such as music and art is a waste of energy and time and much more complicated than necessary for survival concerns. Darwin's (1871) notion that ornamentations in nature are the results of sexual courtship and that human language and music evolved like the bird song for courtship led some scholars 
(e.g. Miller, 2001; Bickerton, 2002) to tackle language as an adaptive ornamentation. Nonetheless, whether the components which constitute the complexity of grammar can be attributed to the adaptations caused by sexual selection makes up one of the discussions on language evolution.

Sexual selection also suggests solutions to the evolution of human larger brain and intelligence, both of which may have been followed by the evolution of language. Accordingly, human intelligence evolved in response to social challenges, the most important of which is mating. Lying, gossip, courtship, manipulation, symbolic thought all are regarded as problem solving mechanisms or strategies. They must have evolved to cope with romance, sex, love, divorce, deception, infidelity, and breaking up (see Dor, 2017 for lying; Dunbar, 1996 for gossip; Buss, 1994; Miller, 2001 for courtship; Wray, 1998 for manipulation; Pfeiffer, 1982; Bickerton, 1990; d'Errico and Vanhaeren, 2009; Tallerman, 2014; Tattersall, 2014). Dor (2017, p. 45) points out that language co-evolved with lying. Evolutionary psychologist Geoffrey Miller's (2001) notation of mutual interest which proposes that courtship is sustainable only if mates have mutual acquaintances such as gossip coincides with Dunbar's (1996) allegation that larger brains evolved in response to social relationships among primates. As for other primate researchers such as Whiten and Byrne (1988), it is suggested that Machiavellian intelligence as a mating strategy resorted to deceive other mating competitors contributed to the transition from monkey brains to ape brains. Dunbar (1996) also suggests that social behaviors such as altruism, kin selection, kindness, morality all are side effects of sexual selection, which may rank above intelligence, beauty, and status. And according to Miller (2001), since speaking costs time and energy, the emergence of language itself may have been a kind of altruistic behavior. One evidence put forward by Miller (2001) for this is the difference between our hearing and speaking hardware. While our hearing hardware is almost the same as other primates, our speaking hardware is almost disparate. Our thought is also claimed to have been subject to sexual selection after language come out as a courtship medium (Miller, 2001, p.10). Moreover, the developments in art, medicine, technology, industry, science, architecture, and arms all are sorts of courtship adaptations (Miller, 2001, p. 22; see also Whiten and Byrne, 1988 for military competition and Kohn (2000) for the development of hand axes). In conclusion, our many behaviors, skills, social strategies as well as intelligence, thought and creativity evolved as a courtship adaptation to sexual selection pressures. Herewith, language as a socially woven communication medium cannot be considered independently of our sexually woven mating mind. As stated by Miller (2001, p. 135, 387) just like in the case of birds' songs evolved in response to sexual selection, human language, art, and music have been evolved to say nothing other than "I am fit, mate with me".

\section{Combinatorial patterns and symbolic thought in the phylogeny of copulation}

Sex encapsulates more than reproduction. It seems a kind of tenet, or guideline, to cope with survival challenges (Chisholm, 1999). The characteristic patterns of sex observed among animal and plant life display a common combinatorial system of mounting of a seed into an ovum. Locking, thrusting during intromissions, and multiple intromissions are frequent copulatory patterns among primates (Dewsbury and Pierce, 1989). As for human copulation, "stimulation (or pressure, friction, vibration), the area of stimulation (e.g. clitoris, vagina), a specific pattern of muscular activity, mobilization or immobilization of the body are the fundamental characteristics of basic sexual behavior" (Bischof-Campbell et al., 2019, p. 357). Basic sexual behavior is also characterized as "slow, rhythmic, gliding back-and-forth rocking motion" of the body during vaginal intercourse" (Kaplan, 1992, p. 285; see also Eichel et al., 1988).

Bipedalism evolved before the large human brain or the development of stone tools according to the fossil evidence from Sahelanthropus, Australopithecus, and Ardipithecus ramidus dating back 7-3.9 million years ago (see McHenry, 1994; Lovejoy, 1988). However, modern human pelvic anatomy fully shaped by bipedalism must have been over 100 thousand years (Gruss and Schmitt, 2015). It means that bipedalism was the antecedent of all developments such as symbolic thought, language, ventro-ventral sex, composite tool production and even the control of fire etc. in human evolution (for symbolic thoughtsee d'Errico and Nowell, 2000; for archaeological evidence see McBrearty and Brooks, 2000; McBrearty, 2007; d'Errico and Vanhaeren, 2009; for the control of fire see Roebroeks and Villa, 2011). As observed among other male primates, bipedal standing may have evolved to display penises to potential mates (Miller, 2001). American actress, comedian, writer, and singer Lily Tomlin interpreted this uprising in her famous ironic statement that "we have reason to believe that man first walked upright to free his hands for masturbation."

Although there are several studies on the side effects of bipedalism on human evolution (e.g. Tuttle, 1981; Gatesy and Middleton, 1997), one of the suggestions is quite remarkable: shift from ventro-dorsal mounting to face-to-face, or eye-to-eye, ventro-ventral copulation. Gallup (2015) suggests that ventro-ventral sex is a byproduct of bipedalism which qualitatively 
changed the course of human sexuality. According to the scientists from the Wildlife Conservation Society (2008), apart from humans, except for a few cases like mountain and Western gorillas, very rare examples among insects (Huber et al., 2007), and a few rodent cases (Dufour et al., 2015), only bonobos, the closest extant relative to humans, frequently employ ventroventral mating positions. Curiously enough, they are also known for their distinctive rocking sexual behavior and tongue kissing, and sex plays an important role in their society (Manson et al., 1997; King, 2004). Indeed, according to Dixson (1998), when the penis rubs the clitoris, unlike the ventro-dorsal mounting, ventroventral coitus posture facilitates clitoral stimulation and sexual pleasure in apes. Furthermore, Dufuour et al. (2015, p. 1020) observed that rodents performing ventro-ventral copulation "spent more time investigating each other" than those not performing ventro-ventral copulation, "and the females were found to be more sexually proactive than the males." According to their observations (Dufuour et al., 2015, p. 1018), moreover, it is "female sexual arousal that may lead to ventroventral coitus posture." In addition, in their research of the ventro-ventral sexual behaviors in bonobos, Palagi et al. (2020) states that in bonobos face to face sexual intercourse could have favored the evolution of specific sexual facial expressions and their rapid mirror replication. In another study, Annicchiarico et al. (2020) found out that homosexual ventro-ventral, or genito-genital rubbing between female bonobos facilitates conflict resolution, anxiety reduction and social bonding. As observed among female Japanese macaques (Sommer and Vasey, 2006), same-sex sexual behavior, or sex for pleasure, demonstrates us that pleasure is dominant in ventro-ventral sexual behavior (see also Hull et al., 2002; Balcombe, 2009). Miller (2001, p. 241) describes penis "as a metaphor for the mind's sexually selected entertainment abilities", and "clitoris as a metaphor for the mind's judgment and discrimination abilities". Therefore, the effect of ventro-ventral posture on females and pleasure cannot be underestimated in having shaped sexual selection and courtship adaptations by the time an African woman, who Bickerton (2002) calls 'African Eve', developed syntax through a single mutation and reshaped the brain and the vocal tract accordingly. This single mutation probably caused by ventro-ventral sex also seems to have been symbolized as the forbidden fruit in Adam's and Eve's myth. In this archetypal myth, the forbidden fruit from the tree of the knowledge of good and evil symbolizes the ancestral sin which can be attributed to sexual or linguistic arousal (Golitzin, 1995; for the original sin see Brodd, 2003).

Through ventro-ventral sex, lips and tongues having been used for nutrition also took part in sexual affairs. This combination was also reinforced by the female orgasm (Morris, 1967). Human penis as a sperm delivering extremity and vagina with clitoris as the host as well as human tongue and lips with nutritional and tasting functions made up a recursive, repetitive, embedding, and hierarchical sexual course. They evolved to become sources of rhythmic pleasure (see also Miller, 2001, p. 237, 240 for the function of clitoris in pleasure and orgasm during copulation). It is not implausible to think that this sort of ventroventral, or face-to-face, copulation technique having been experienced for millions of years may have had a gradual cognitive impact on primitive symbolic thought. The Ventro-ventral Mind scenario may be an explanation for the emergence of several human particular features and abilities including the development of large brain, creativity, tool-making, symbolic thought, pleasure, aesthetics, love, art, and language. Within evolutionary perspective, upright posture, verbal language, and sexual affairs are described as adaptations for reproductive fitness by natural selection (Kauth, 2007). On the other hand, Miller (2001, p. 171) advocates that human activities such as art, language, morality and creativity evolved originally as courtship adaptations in response to sexual selection. He regards them as "nothing more than a slightly novel design for a penis, a minor variation in mating coloration, or a different style of courtship dance".

Homo sapiens is thought to have "descended from a non-symbolic and non-linguistic ancestor" (Bickerton, 2017). The development of symbolic thought as the origin of several developments in the ontogeny of human mental abilities coincides with the development of ventro-ventral sex. According to Tattersall (2014), symbolic thought and language are unique to human and language originated from our ancestors' symbolic thought. Likewise, as concluded from the literature reviewed in this paper, ventro-ventral sexual behavior and symbolic thought are unique to human except for a few rare cases observed in the phylogeny and symbolic thought synchronically or diachronically follows our ancestors' eye-to-eye ventro-ventral sexual experience. As in other species that reproduce sexually, there is no other way to merge one's genes with another individual's, or to embed the penis into the vagina, in a recursive copulative course in order to produce an offspring. However, what makes it unique to human is the accompanying higher degree of ventro-ventral pleasure and symbolic thought. Raw primitive combinatorial thought accompanied by face-to-face copulation combined sexual pleasure with facial beauty, which can be assumed to have led to the emergence of symbolic thought, love, art, aesthetics etc. Dufuour at al. (2015, p. 1019) observed and described rodents performing ventro-ventral and ventro-dorsal copulation and found that while performing ventroventral copulation, both the male and the female show 
active pelvic movements. The combinatorial abilities such as recursion, repetition and merge which may have been developed due to this rhythmic pleasure of copulation in phylogeny resulted in symbolic thought in the ontogeny. That is to say, pleasure may have been the trigger of symbolic thought. Art, itself, is described as "the sex of the imagination" (Nathan, 1972, p. 7). Sigmund Freud (1905 as cited in Strachey, 1957) argued that sexual desire was the primary motivating energy in human life and artistic display results from sublimated sexuality (see also Forrester, 1980, p. 111). Indeed, nonreproductive sexual behaviors displayed for the sake of sexual pleasure are usually accompanied with nonreproductive behaviors such as kissing, masturbation or oral sex even among heterosexuals. Moreover, masturbation is another imaginative sexual trait with a symbolic unreal sexual object, resulting in sexual pleasure (see also Laqueur, 2003, p. 210). Therefore, it can also be claimed that our mind runs after pleasure, which reinforces learning and self-improvement (Miller, 2001, p. 150). Archaeological evidence such as shell beads, body ornaments or knots dating back to 130 90 thousand years ago are claimed to display symbolic behavior (for further interpretation of archaeological evidence see McBrearty and Brooks, 2000; d'Errico and Vanhaeren, 2009). Other archaeological evidence even dating back to 500-200 thousand years ago indicates that art and symbolic thought could have evolved far earlier (d'Errico and Nowell, 2000; Bednarik, 2003). Moreover, Miller (2001, p. 263) mentions "Paleolithic pornography" pointing to late Paleolithic statues of a naked woman usually described as goddess or a fertility symbol by other archaeologists. The presence of symbolic artefacts in archaeological records also indicates the presence of language and creative imagination at that time (see Botha, 2009; Chomsky, 2010; Tattersall, 2014).

Language itself is a part of complex human behavior and ecological system (see Garner, 2004, p. 112, 116 for the view of language as an ecological system and social behavior). Since it has combinatorial characteristics such as hierarchy, merge and recursion originated in human mind and phonetic forms finally articulated through tongues and lips, it cannot be considered isolated from pleasure. The link between symbolic behavior and language has been questioned in large bodies of literature (e.g. Pfeiffer, 1982; Bickerton, 1990; d'Errico and Vanhaeren, 2009; Tallerman, 2014; Tattersall, 2014). Pfeiffer (1982) claims that abstract and symbolic thinking must have led to the emergence of art, music, language, religion and technological innovation. Tattersall (2014, p. 199-201) regards language as the "ultimate symbolic activity." The capacities that set humans apart from all other known animals include capacities for art, music, dance, abstract thought, use of symbols and the ability to reason abstractly about others and about events, as well as the ability to manipulate symbols recursively and syntactically (Tse, 2008, p. 270). Foster (1996) and Banes (1998) carried out movement discourse analysis on modern human dance and these movements were also associated with linguistic analysis (Hanna, 2010). Accordingly, dance is performed through a system of small movements, or units, combining to make figures with rhythm and harmony, or sentences with phrasal structures, which finally combine to make a whole dance, or discourse (Hanna, 2010). What makes this analysis interesting is that it associates the repetitive and recursive movements and nits combining to make figures with rhythm and harmony with phrasal structures in sentences. Moreover, as to the evidence from experimental archaeology cited by Tallerman (2014, p. 216), there is evidence for the correlation between neural circuits involved in manual practices and those involved in language. She also shows evidence for the emergence of composite tools and hafting manufactured by using highly complex adhesive or binding technique dating back to around 300,000 years ago (see McBrearty and Brooks, 2000; Mc Brearty, 2007; Roebroeks and Villa, 2011 for the archaeological evidence). Accordingly, she regards hafting as an indicator of a cognitive merge, and claims that cognitive merging must have been in practice for more than 100,000 years. On basis of the archaeological evidence reviewed in the literature so far, it must have been at least for 400,000 years. Primate studies on mountain gorillas and chimpanzees, in addition, offer experimental evidence of hierarchical reasoning and recursion (see Byrne and Russon, 1998; Bergman et al., 2003). Furthermore, Okanoya (2002) argues that bird songs display a complex hierarchical organization with embedding recursive operations. Calvin (1983) also establishes a relation between hand control and language during the left-brain specialization. Similarly, Greenfield (1991, p. 539) points out that manual object combinations and first word formations appear at the same time around the age of two, which also demonstrates that Broca's area is implicated in both types of combination. Neuropsychologist and linguist Angela Friederici (2011) clarifies this issue claiming that hierarchical abilities are executed by the same neural mechanisms within Broca's area. Language as a symbolic, hierarchical, iterative, and productive system also occurred as a byproduct of complex symbolic manipulations exploited through our imagination and combinatorial creativity.

As a consequence of all these findings, it can be concluded that reproduction, generation, symbolism, gender, sexual orientations, hierarchy, iteration, repetition, merge and recursion appear as common combinatorial patterns in the phylogeny. 
Table 1. Gender based representation of syntactical categories

\begin{tabular}{|c|c|c|c|}
\hline Representation & Gender & Category & Function in syntax \\
\hline & masculine & nouns & complement \\
\hline & feminine & prepositions & host \\
\hline etc. & feminine & $\begin{array}{c}\text { functional categories } \\
\text { (tense, complementiser, aspect, determiner } \\
\text { etc.) }\end{array}$ & host \\
\hline & androgynous & $\begin{array}{c}\text { verbs } \\
\text { (transitive/intransitive) }\end{array}$ & host/complement \\
\hline & neutral & adjectives, adverbs & adjunct \\
\hline
\end{tabular}

\section{Ancestral characters in the ontogeny of grammar}

Grammar has a combinatorial system called syntax, which manipulates single items to form a more complex structure by combining them just like the other combinatorial patterns in the phylogeny (Bickerton 1990; Pinker, 2003; Tallerman, 2008). Actually, all syntax, building phrase structures, morphology, lexicon, phonological rules and structures are assumed as the products of this combinatorial system (see Bickerton, 1990; Pinker, 2003; Zywiczynski et al., 2017 for combinatorial debates). The mechanism underlying this combinatorial system is a simple recursive operation called merge. Merge, as an essential cognitive development, is a recursive syntactic ability to form infinite combinatorial sets of synthetic structures from finite lexical items, which "makes language something much more than an animal communication system" (see Berwick and Chomsky, 2016, p. 3). What it takes to merge words to construct more complex hierarchical phrasal structures is "a word-chain device, a discrete combinatorial system" (Pinker, 2003, p. 92). Binary phrasal structure is an outcome of this discrete combinatorial system, "since it is capable of creating an unlimited number of distinct combinations from a finite set of elements" (Pinker, 2003, p. 92). It is made up of a host, or head, and a complement. It is the hierarchical ordering of phrases embedded within other phrases, resulting in recursion (Parker, 2006). According to Forrester (1980), there is a close relationship between sex and symbolism, which may have taken part in the origin and development of speech (see also Freud, 1916 as cited in Strachey, 1963 for dreams, symbolism, language and sexuality). In fact, modern human language harbors syntactical, morphological or semantical archaic traces associated with sexuality: grammatical genders, lexical or functional categories serving as complements or heads (i.e. hosts), merging, recursivity etc. Semantically, for instance, the word er refers to muscular third person singular in German, man, soldier, or copular verb in Turkish, Eros as the god of love and sex in Greek mythology etc. In dreams or in real life, words such as jewel, jewel case, treasure and sweet are used to describe the beloved one (Freud, 1916 as cited in Strachey, 1963; Forrester, 1980). Furthermore, some languages (e.g. French, Russian, Arabic) attribute gender (e.g. masculine, feminine, or neuter) to certain lexical categories such as nouns, pronouns, adjectives etc. (see Ibrahim, 2014 for the origin and development of grammatical gender). S Seker (2017), besides, outlines the grammatical gender features and sexual characteristics of syntactical categories and revised phrase structure operations within a gender and sex based psychoanalytic perspective. Although the study is not firmly grounded, it is notable enough to illustrate the combinatorial system of merge and recursivity with gender based and sexually oriented representations of syntactical categories.

Table 1 lists the combinatorial representations of functional and lexical categories in terms of their functions and genders (Şeker, 2017).

Accordingly, nouns are symbolically masculine in terms of gender since they cannot be completed by any complement but modified by an adjunct (e.g. big bag). On the other hand, transitive verbs as well as auxiliaries are symbolically androgynous in terms of gender since 
they may or may not require a complement (e.g. run well or read a book). Verbs, in general, may also be modified by adverbial adjuncts symbolically demonstrating neutral gender features. Furthermore, functional categories such as complementizers are also symbolically feminine since they are completed by phrasal structures (e.g. that I saw or with his friend).

Following the chart listing the combinatorial representations of functional and lexical categories in terms of their functions and genders above, the syntactical representations developed out of the gender based building-block illustrations in Şeker (2017) demonstrate the symbolic, generative, combinatorial, gendered, and recursive patterns in the ontogeny of grammar. In Figure 1, the syntactical structure of the complementizer phrase (CP) that the mechanism works well is analyzed through building blocks modelling.

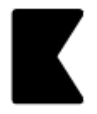

that

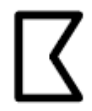

the

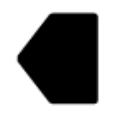

mechanism

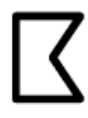

tense

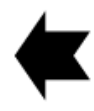

work

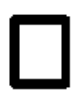

well
Figure 1. Gender based representations of the syntatical elements in a $C P$

In Figure 2, the intransitive verb work is modified by the adverb well to generate the verb phrase (VP) work well.

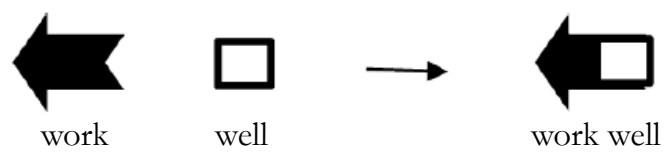

Figure 2. Formation of the VP

In Figure 3, the resulting symbolically masculine VP work well merges with the attracting host tense (T-Present-PRE-) generating the tense phrase (TP) PRE work well, but still requiring feature checking for person and number.

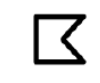

tense (PRE)

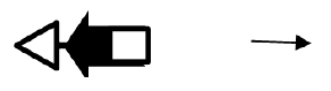

work well

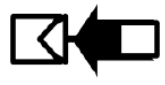

PRE work well (-person/-number)
Figure 3. Embedding the VP into T

In Figure 4, the resulting symbolically masculine TP works well which requires a specifier is specified by the determiner phrase (DP) the mechanism with third person singular features (3Per.Sin.), eventually generating the TP the mechanism works well.

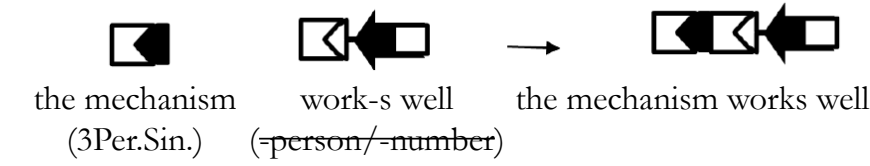

Figure 4. Feature checking in TP

In Figure 5, the resulting symbolically masculine TP the mechanism works well, then, merges with the feminine host constituent that which functions as a complementizer (C), eventually gerating the complementizer phrase (CP) that the mechanism works well as in Figure 6.

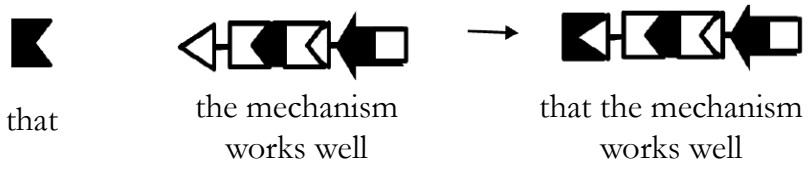

Figure 5. Embedding the TP into $C$

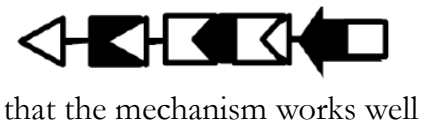

Figure 6. The resulting representation of the recursive structures as $C P$

Şeker (2017) also points out a-merger, bi-merger, and hetero-merger orientations of the syntactical relations between lexical categories. Although it is not firmly grounded enough, the assertion does not sound implausible when the phrase structures above are taken into account. Accordingly, the VP work well is a-merging since the intransitive verb work does not require a masculine complement but it is modified by the adverb well, functioning as an adjunct. While DPs operate hetero-merging since determiners are feminine in gender and habitually select nouns as a masculine category (e.g. the mechanism), noun phrases (NPs) like school bus is homo-merging since both lexical constituents are nouns and masculine.

As illustrated above, these hierarchically organized, serially ordered, symbolic as well as sexually oriented combinatorial patterns, thus, outline the fundamental ancestral characters such as combination, grammatical gender, hierarchy, merge and recursivity in the ontogeny of grammar. This discrete system makes human language "infinite and compositional, which bears resemblance to the genetic code in DNA, where four kinds of nucleotides are combined into an unlimited number of different genes" (Pinker, 2003, p. 84, 334). Merge is presumed to have emerged in hominin cognition sometime between 50,000 and 100,000 (see Berwick et al., 2013), or 200,000 years ago and developed gradually (see Tallerman, 2014). It grew out of internal thought and was an adaptive problem-solving mechanism (Tallerman, 2014, p. 207; see also Chomsky, 2010, p. 
55 for internalization as the earliest stage of language). Since internal thought involves "conceptualization and the core principles of human syntax" (Berwick et al., 2013, p. 91), it is plausible to correlate it synchronically with symbolic thought. Recursion is not only unique to language but also to human mind and it is equated with repetition (Parker, 2006). Considering the difficulties in its comprehension even among adults, Christiansen and Chater (1999) suggest that recursion was a later stage in phylogeny and ontogeny of language. Although it could be introduced as an innate linguistic feature, recursion must have been learned by a gradual connectionist network, or a combinatorial system (Christiansen and Chater, 1999). Syntax as a whole system is a hierarchically organized and serially ordered product of combinatorial system, characterizing many complex mental systems shaped by symbolic and combinatorial patterns and other psychological mechanisms of the human mind (Simon, 1969). This makes it possible to propose that "grammar and thought are not two independent domains" (Hinzen, 2012, p. 639) and that "just as there is a universal design to the computations of grammar, there is a universal design to the rest of the human mind" (Pinker, 2003, p. 410). In conclusion, a combinatorial system characterized by hierarchy, repetition, recursivity and merge is common not only in the phylogeny of hierarchical or combinatorial abilities in general (i.e. among hominids, primates as well as other species) but also in the ontogeny of grammar in particular.

\section{Recaputilation of the combinatorial patterns in the ontogeny of grammar}

Hurford (2003, p. 45) claims that "apes have mental representations in predicate-argument form." Therefore, protogrammar is assumed to have "evolved from Homo habilis (about 2.4-1.5 million years ago) and Homo erectus (about 1.9-0.2 million years ago)", or even before hominids split from the chimpanzee genus Pan (about 6-7 million years ago). Pinker (2003) concludes that since then, about 350,000 generations or more have paraded on Earth, which gave enough time "for the ability to have been elaborated and fine-tuned to the Universal Grammar we have today" (Pinker, 2003, p. 346). In his earlier works, Chomsky (1965) who suggests "an innate Universal Grammar for the machinery underlying the world's language" processed by language faculty initially opposed the idea of protogrammar, claiming that human linguistic system is quite different from animals' communication system (Pinker, 2003, p. 409). However, in his later studies (e.g. Hauser et al., 2002), he left the door open for the idea of protogrammar in favor of the lexically operated sensory-motor system, but still not for the syntactic formations generated by recursive combinatorial operations. According to Miller (2001), moreover, innateness is not a relevant explication for language faculty in modern evolutionary theory. In evolutionary perspective, in fact, language faculty is an "adaptive response to evolutionary pressures" (Barkow et al., 1992, p. 475). Likewise, Benítez-Burraco (2017) also supports the adaptive characteristic of grammar and proposes that changes in social cognition affects grammaticalization. Accordingly, evolution of grammar is a gradual continuous process and, hence, it is possible to envisage "more complex and specialized universal grammars" (Barkow et al., 1992, p. 478). In contrast, Chomsky's (2012) notion of Innate Universal Grammar appears as a language-ready brain as a set of peculiar cognitive capacities developed quite suddenly (see also Arbib, 2012). Nonetheless, combinatorial characters such as hierarchy, merge and recursion may have been appeared in the phylogeny of combinatorial system long before any sudden Homo activity like bipedalism, or ventro-ventral sexual behavior since this kind of behaviors can be observed among other species. The iterative experience of rhythmic pleasure has been experienced not only through ventro-ventral sexual behavior but also ventro-dorsal mounting as among other species. Therefore, combinatorial capabilities are not unique to ontogeny but to phylogeny, which can also be observed among other species.

Mental language mechanisms such as merge and recursivity are embedded in accumulated human experiences (Pinker, 2003). That is, the combinatorial system characterizing the ontogeny of grammar can also be observed in most of the complicated systems operated by humans, ranging from tool-making, cooking, and painting to composing music, building, and manufacturing. In all these structures, "discrete properties of smaller units are combined to form a higher product with new discrete properties" (Pinker, 2003, p. 85). In this context, there exists a vast literature on the relation between the evolutionary mechanisms involved in the development of protogrammar and those involved in other human mental developments. Construction of composite tools has long been associated with composite thought or language (e.g. Greenfield, 1991; see also Bouchard, 2013; Tallerman, 2014 for further arguments). Bouchard (2013), for example, establishes a link between production of symbolic artefacts and the generation of syntax. Pinker (2003) describes the evolution from protolanguage to language as less applied rules followed by morphological structures. In later stages, protogrammar must have been processing lexical items (most probably nouns and verbs) even for "the functions undertaken by the morphological units in today's sophisticated grammar" (Zywiczynski et al., 2017, p. 2). All grammatical morphemes and other 
Table 2. Comparison of combinatorial characters in copulation and grammar

\begin{tabular}{|c|c|c|}
\hline Characteristics & Copulation (Phylogeny) & Grammar (Ontogeny) \\
\hline Iterative / Repetitive & Pelvic movements, rocking & Recursion \\
\hline Combinatory & Copulation & Merge \\
\hline Productive & Reproduction & Generation, derivation \\
\hline Hierarchical & Female / male & Host / complement \\
\hline Gendered & Feminine / masculine/ androgynous & Feminine / masculine/ androgynous \\
\hline Symbolic & $\begin{array}{l}\text { Non-productive sex, masturbation, } \\
\text { kissing }\end{array}$ & $\begin{array}{c}\text { Phonemes, morphemes, lexemes, innate } \\
\text { principles }\end{array}$ \\
\hline Sexual & $\begin{array}{l}\text { Heterosexuality, homosexuality, } \\
\text { bisexuality, asexuality }\end{array}$ & $\begin{array}{l}\text { Hetero-merging, homo-merging, } \\
\text { bi-merging, a-merging }\end{array}$ \\
\hline
\end{tabular}

categories are assumed to have been derived from nouns and verbs through grammaticalization (see Bickerton, 1990; Hurford, 2003; Tallerman, 2008; Zywiczynski et al., 2017). Tallerman (2008, p. 117) contributes to this assumption, suggesting that there were empty categories in protolanguage (like the null hypothesis in UG), only requiring nouns and verbs, but no other categories to generate more complex structures. She grounds her opinion on some pragmatic evidence in modern grammar "just in the case of the development of pidgins into full languages" (Tallerman, 2008, p. 117). Miller (2001) also promotes this grounding, stating that pidgin and artificial languages work with very small vocabulary and minimal grammar, mentioning about "a stripped-down English vocabulary of just 850 words called Basic English” (Miller, 2001, p. 307). Illustrating similar evidence from ungrammatical daily conversations and awkward, witty verbal courtship of teenagers, he proceeds with a model for the protogrammar of our ancestors (Miller, 2001, p. 352, 361). In other words, as in other species that reproduce sexually, there is no other way to merge one's genes with another individual's, or to embed the penis into the vagina, in a recursive copulative course in order to produce an offspring. Likewise, there is no other way to merge one signifier with another one in order to produce a sentence. Thus, having been experienced with and reinforced by pleasure for long enough to reason abstractly and to manipulate symbols recursively and syntactically, ventro-ventral sexual behavior led to symbolic thought in the ontogeny. Symbolic thought, then, led to a symbolic protolanguage, the protogrammar of which was shaped by a combinatorial system recapitulating sexual, or copulatory, behaviors in the phylogeny, which made our ancestors put the early phonemes and lexemes together. Table 2 illustrates the comparison of combinatorial characters described for copulation and grammar in the literature review so far.

Accordingly, the ancestral characters such as generation, symbolism, hierarchy, gender, merge and recursivity in the ontogeny match with other reproductive, symbolic, sexual, combinatorial, hierarchical, iterative, repetitive, recursive experiences in the phylogeny. By comparing the combinatorial characteristics of the copulatory patterns in the phylogeny with the grammatical ones in the ontogeny, I conclude that these combinatorial mental mechanisms are confined neither to grammar nor to human. In fact, generation, symbolism, hierarchy, gender, merge and recursivity must be regressions to earlier more comprehensive common ancestral mental mechanisms in phylogeny. On this ground, it is not implausible to postulate that generation, symbolism, hierarchy, gender, merge and recursivity in the ontogeny of grammar could be regressions to earlier evolutionary stages of copulation. Recapitulation Theory by German naturalist and philosopher Ernst Haeckel (1866), as cited by Gilbert (2006), postulates that "ontogeny recapitulates phylogeny", that is, "embryonic development of an individual organism (ontogeny) traces the evolutionary development of the species (phylogeny)." In his book The History of Creation, originally published in 1899 and revived in 2019, referring to his theory of recapitulation, he also posits that "pathological states of mind could be regressions to earlier evolutionary stages of mammalian and reptilian development." This proposition is significant in that mental states can follow the path of the earlier evolutionary mental stages as well. Therefore, based on the opinions and evidence outlined in this part of the paper, I propose that the fundamental grammatical characteristics such as generation, symbolism, hierarchy, gender, merge, and recursion are regressions to productive, symbolic, sexual, combinatorial, hierarchical, iterative, repetitive, recursive copulatory experiences in the phylogeny. That is to say, copulatory patterns, particularly ventro-ventral sexual behavior, in the phylogeny made our ancestors 
put the words together into a human specific language and the things together into more complex tools.

\section{Conclusion}

In this paper, I initially introduced a holistic view of evolutionary ideas relating to language evolution and the nature of adaptations through mating in terms of sexual selection in order to demonstrate that sex is predominant in the emergence of protolanguage and that language and sex are interrelated. Next, on a structural base, recursivity and merge operations as the underlying mental language mechanisms were described and discussed not only in the ontogeny of grammar but also in the phylogeny of hierarchical abilities in general. Accordingly, it was concluded that merge and recursivity must be regressions to an earlier common ancestral mental mechanism since they are observed not only in almost every human development but also combinatorial abilities among primates or in other species as well. Repetition, merge, recursion, and hierarchy were identified as common ancestral characters between the combinatorial system of grammar and the copulatory activity. In other words, copulation, either ventro-dorsal or ventro-ventral, was introduced as the origin, or antecedent, of combinatorial system of merge and recursion observed in several developments in human mental evolution. However, symbolic thought as the origin of several developments in the ontogeny of human mental abilities coincides with the development of ventro-ventralsex. This grounding led to the postulation that generation, symbolism, hierarchy, gender, merge and recursion in the ontogeny of grammar are regressions to earlier evolutionary productive, symbolic, sexual, combinatorial, hierarchical, iterative, repetitive, recursive experiences in ontogeny and phylogeny. The relation between sex and mental language mechanisms encapsulates more than holistic adaptations. Structurally, merge and recursivity are just parts of overall repetitive, iterative, combinatorial and rocking behaviors in ontogeny and phylogeny. Holistically, on the other hand, rituals, ceremonies, prayers, worship, music, dance, poetry, chants, hymns, rhymes, tics, masturbation, as well as symbolic thought and language all can be seen as regressions to, or the side effects of, ventro-ventral sex which changed the course of pleasure among our ancestors. Ventro-ventral mechanism is a state of deeper primitive mind, or a state of competency, looking upon every affair as a copulative function of penis, as the complement, going into the vagina, as the host, within a recursive combinatorial mechanism. It brought the ability of achieving rhythmic pleasure through a symbolic course. Apart from symbolic thought, language is the forbidden fruit from the tree of knowledge achieved through the ancestral sin.

\section{References}

Andersson, M. (1994). Sexual selection. Princeton University Press.

Annicchiarico, G., Bertini, M., Cordoni, G., \& Palagi, E. (2020). Look at me while having sex! Eye-to-eye contact affects homosexual behaviour in bonobo females. Behaviour, 157(1011), 949-970. https://doi.org/10.1163/1568539X-bja10034

Arbib, M. A. (2012). How the brain got language: The mirror system bypothesis. Oxford University Press. https://doi.org/10.1093/ acprof:osobl/9780199896684.001.0001

Balcombe, J. (2009). Animal pleasure and its moral significance. Applied Animal Behaviour Science, 118(3-4), 208216. https://doi.org/10.1016/j.applanim.2009.02.012

Banes, S. (1998). Dancing women: Female bodies on stage. Routledge.

Barkow, J. H., Cosmides, L., \& Tooby, J. (Eds.). (1992). The adapted mind: Evolutionary psychology and the generation of culture. Oxford University Press.

Bednarik, R. (2003). A figurine from the African Acheulian. Current Anthropology, 44(3), 405-413. https://doi.org/10.1086/374900

Benitez-Burraco, A. (2017). Grammaticalization and language evolution: focusing the debate. Language Sciences, 63, 60-68. https://doi.org/10.1016/j.langsci.2017.03.003

Bergman, T., Beehner, J., Cheney, D. \& Seyfarth, R. (2003). Hierarchical classification by rank and kinship in baboons. Science, 302(5648), 1234-1236. https://doi.org/10.1126/ science.1087513

Berwick, R. C., Friederici, A. D., Chomsky, N., \& Bolhuis, J. J. (2013). Evolution, brain, and the nature of language. Trends in Cognitive Sciences, 17(2), 89-98. https://doi.org/10.1016/i. tics.2012.12.002

Berwick, R. C., \& Chomsky, N. (2016). Why only us: Language and evolution. MIT press. https://doi.org/10.7551/ mitpress/10684.001.0001

Bickerton, D. (1990). Language and species. University of Chicago Press. https://doi.org/10.7208/chicago/9780226220949.001.0001

Bickerton, D. (2002). From protolanguage to language. in T. J. Crow (Ed.). The speciation of modern Homo sapiens (pp. 103120). British Academy Scholarship Online. https://doi.org/ $10.5871 / \mathrm{bacad} / 9780197263112.003 .0006$

Bickerton, D. (2017). Language and human behavior. University of Washington Press.

Bickerton, D., \& Szathmáry, E. (Eds.). (2009). Biological foundations and origins of syntax. MIT Press. https://doi.org/10.7551/ mitpress/9780262013567.001.0001

Bischof-Campbell, A., Hilpert, P., Burri, A., \& Bischof, K. (2019). Body movement is associated with orgasm during vaginal intercourse in women. The Journal of Sex Research, 56(3), 356366. https://doi.org/10.1080/00224499.2018.1531367

Bolinger, D. (1980). Language: The loaded weapon. Longman.

Botha, R. (2009). Theoretical underpinnings of inferences about language evolution: the syntax used at Blombos Cave. The Cradle of Language, 12, 93.

Bouchard, D. (2013). The nature and origin of language. Oxford University Press. https://doi.org/10.1093/ acprof:oso/9780199681624.001.0001 
Brodd, J. (2003). World religions. Saint Mary's Press.

Byrne, R., \& Russon, A. (1998) Learning by imitation: A hierarchical approach. Behavioral and Brain Sciences, 21(5), 667-721. https:// doi.org/10.1017/S0140525X98001745

Buss, D.M. (1994). The evolution of desire: Strategies of buman mating. Basic Books.

Calvin, W. H. (1983). A stone's throw and its launch window: Timing precision and its implications for language and hominid brains. Journal of theoretical Biology, 104(1), 121-135. https://doi.org/10.1016/0022-5193(83)90405-8

Calvin, W. H., \& Bickerton, D. (2001). Lingua ex machina: Reconciling Darwin and Chomsky with the human brain. MIT Press. https:// doi.org/10.7551/mitpress/4246.001.0001

Campbell, D. T. (1974). Downward causation'in hierarchically organised biological systems. In F. J. Ayala \& T. Dobzhansky (Eds.), Studies in the Philosophy of Biology (pp. 179-186). Palgrave. https://doi.org/10.1007/978-1-349-01892-5_11

Chisholm, J. S. (1999). Death, hope and sex: Steps to an evolutionary ecology of mind and morality. Cambridge University Press. https://doi. org/10.1017/CBO9780511605932

Chomsky, N. (1965). Aspects of the Theory of Syntax. The MIT Press.

Chomsky, N. (1991). Linguistics and cognitive science: Problems and mysteries. In A. Kasher (Ed.), The Chomskyan turn (pp. 26-53). Blackwell.

Chomsky, N. (2010). Some simple evo devo theses: How true might they be for language. In R. K. Larson, V. Déprez \& H. Yamakido (Eds.). The evolution of human language: Biolinguistic perspectives (pp. 54-62). Cambridge University Press. https:// doi.org/10.1017/CBO9780511817755.003

Chomsky, N. (2012). The Science of language: Interviews with James McGiluray. Cambridge University Press. https://doi. org/10.1017/CBO9781139061018

Christiansen, M. H., \& Chater, N. (1999). Toward a connectionist model of recursion in human linguistic performance. Cognitive Science, 23(2), 157-205. https://doi.org/10.1207/ s15516709 $\operatorname{cog} 23022$

Darwin, C. (1871). The descent of man and selection in relation to sex. http://hdl.handle.net/11858/00-001M-0000-002B0E15-0

Dawkins, R. (1976). Memes: the new replicators. The selfish gene. Oxford University Press.

d'Errico, F., \& Nowell, A. (2000). A new look at the Berekhat Ram figurine: implications for the origins of symbolism. Cambridge Archaeological Journal, 10(1), 123-167. https://doi.org/10.1017/ $\underline{\text { S0959774300000056 }}$

d'Errico, F., \& Vanhaeren, M. (2009). Earliest personal ornaments and their significance for the origin of language debate. The Cradle of Language, 12, 16.

Dewsbury, D. A., \& Pierce Jr, J. D. (1989). Copulatory patterns of primates as viewed in broad mammalian perspective. American Journal of Primatology, 17(1), 51-72. https://doi.org/10.1002/ ajp.1350170106

Dixson, A. (1998). Primate sexuality: comparative studies of the prosimians, monkey, apes and human beings. Oxford University Press.

Dor, D. (2017). The role of the lie in the evolution of human language. Language Sciences, 63, 44-59. https://doi. org/10.1016/j.langsci.2017.01.001
Dufour, C. M. S., Pillay, N., \& Ganem, G. (2015). Ventroventral copulation in a rodent: a female initiative?. Journal of Mammalogy, 96(5), 1017-1023. https://doi.org/10.1093/ imammal/gyv106

Dunbar, R. (1996). Gossip, grooming and the evolution of language. Harvard University Press.

Eichel, E. W., Eichel, J. D., \& Kule, S. (1988). The technique of coital alignment and its relation to female orgasmic response and simultaneous orgasm. Journal of Sex \& Marital Therapy, 14(2), 129-141. https://doi.org/10.1080/00926238808403913

Forrester, J. (1980). Language and the origins of psychoanalysis. Macmillan Press. https:// doi.org/10.1007/978-1-349-04445-0

Foster, S. L. (1996). The ballerina's phallic pointe. In S. L. Foster (Ed.), Corporealities: Dancing knowledge, culture and power (pp. 1-24). Routledge.

Friederici, A. D. (2011). The brain basis of language processing: From structure to function. Physiological Reviews, 91(4), 13571392. https://doi.org/10.1152/physrev.00006.2011

Gallup Jr, G. G. (2015). Bipedalism and sex. In The international encyclopedia of human sexuality, 1-2. https://doi. org/10.1002/9781118896877.wbiehs052

Garner, M. W. J. (2004). Language: An ecological view. Peter Lang Publishers.

Garza-Mercer, F. (2007). The evolution of sexual pleasure. Journal of Psychology \& Human Sexuality, 18(2-3), 107-124. https://doi. org/10.1300/J056v18n02 04

Gatesy, S. M., \& Middleton, K. M. (1997). Bipedalism, flight, and the evolution of theropod locomotor diversity. Journal of Vertebrate Paleontology, 17(2), 308-329. https://doi.org/10.1080 /02724634.1997.10010977

Geher, G., \& Miller, G. (Eds.). (2008). Mating intelligence: Sex, relationships, and the mind's reproductive system. Taylor \& Francis.

Gilbert, S. F. (2006). Developmental Biology, 8th Ed. Sinauer Associates.

Golitzin, A. (1995). On the mystical life, the ethical discourses: St. Symeon the new theologian. SVS Press.

Gould, S. J. (1987). The limits of adaptation: Is language a spandrel of the human brain? Paper presented to the Cognitive Science Seminar. Center for Cognitive Science, MIT, 50.

Greenfield, P. M. (1991). Language, tools and brain: The ontogeny and phylogeny of hierarchically organized sequential behavior. Behavioral and Brain Sciences, 14(4), 531-551. https:// doi.org/10.1017/S0140525X00071235

Gruss, L. T., \& Schmitt, D. (2015). The evolution of the human pelvis: changing adaptations to bipedalism, obstetrics and thermoregulation. Philosophical Transactions of the Royal Society B: Biological Sciences, 370(1663), 20140063. https://doi. org $/ 10.1098 /$ rstb.2014.0063

Hanna, J. L. (2010). Dance and sexuality: Many moves. Journal of sex research, 47(2-3), 212-241. https://doi. org/10.1080/00224491003599744

Hauser, M.D., Chomsky, N., \& Fitch, T. (2002). The faculty of language: what is it, who has it, and how did it evolve? Science, 298(5598), 1569-1580. https://doi.org/10.1126/ science.298.5598.1569

Hinzen, W. (2012). The philosophical significance of Universal Grammar. Language Science, 34(5), 635-649. https://doi. 
$\operatorname{org} / 10.1016 / j$. langsci.2012.03.005

Huber, B. A., Sinclair, B. J., \& Schmitt, M. (2007). The evolution of asymmetric genitalia in spiders and insects. Biological Reviews, 82(4), 647-698. https://doi.org/10.1111/j.1469185X.2007.00029.X

Hurford, J. R. (2003). The language mosaic and its evolution. In M. Christiansen \& S. Kirby (Eds.), Language Evolution (pp. 3857). Oxford Scholarship Online. https://doi.org/10.1093/ acprof:oso/9780199244843.003.0003

Hurford, J. R. (2007). The origins of meaning: Language in the light of evolution. Oxford University Press.

Hull, E. M., Meisel, R. L., \& Sachs, B. D. (2002). Male sexual behavior. In D. Pfaff, A. P. Arnold, S. E. Fahrbach, A. M. Etgen \& R. T. Rubin (Eds.), Hormones, brain and behavior (p. 5-65). Academic Press. https://doi.org/10.1016/B978012532104-4/50003-2

Ibrahim, M. H. (2014). Grammatical gender: its origin and development. Walter de Gruyter.

Johansson, S. (2006). Working backwards from modern language to proto-grammar. In A. Cangelosi, A. D. M. Smith \& K. Smith (Eds.), The evolution of language (pp. 160-167). World Scientific. https://doi.org/10.1142/9789812774262_0021

Kaplan, H. S. (1992). Does the CAT technique enhance female orgasm?. Journal of Sex \& Marital Therapy, 18(4), 285-291. https://doi.org/10.1080/00926239208412853

Kaufman, J. C. (Ed.). (2014). Creativity and mental illness. Cambridge University Press. https://doi.org/10.1017/ CBO9781139128902

Kauth, M. R. (2007). The evolution of human sexuality: An introduction. Journal of Psychology \& Human Sexuality, 18(2-3), 1-22. https://doi.org/10.1300/J056v18n02 01

King, B. J. (2004). The dynamic dance: Nonvocal communication in African great apes. Harvard University Press.

Kohn, M. (2000). As we know it: Coming to terms with an evolved mind. Granta.

Laqueur, T. (2003). Solitary sex: A cultural history of masturbation. Zone Books.

Launer, J. (2014). Sex and sexuality: an evolutionary view. Psychoanalytic Inquiry, 34(8), 831-846. https://doi.org/10. $\underline{1080 / 07351690.2014 .968026}$

Lovejoy, C.O. (1988). Evolution of human walking. Scientific American, 259(5), 82-89. https://doi.org/10.1038/ scientificamerican1188-118

Manson, J. H., Perry, S., \& Parish, A. R. (1997). Non-conceptive sexual behavior in bonobos and capuchins. International Journal of Primatology, 18(5),767-786.

McBrearty, S. (2007). Down with the revolution. In P. Mellars, K. Boyle, O. Bar-Yosef \& C. Stringer, Rethinking the buman revolution (pp. 133-152). McDonald Institute for Archaeological Research

McBrearty, S., \& Brooks, A. S. (2000). The revolution that wasn't: a new interpretation of the origin of modern human behavior. Journal of Human Evolution, 39(5), 453-563. https:// doi.org/10.1006/jhev.2000.0435

McHenry, H. M. (1994). Behavioral ecological implications of early hominid body size. Journal of Human Evolution, 27(1-3), 77-87. https://doi.org/10.1006/jhev.1994.1036
Miller, G. (2001). The mating mind: How sexual choice shaped the evolution of human nature. Anchor.

Morris, D. (1967). The naked ape: A zoologist's study of the human animal. Cape.

Nathan, G. J. (1972). The world in falseface. Fairleigh Dickinson University Press.

Okanoya, K. (2002). Sexual display as a syntactic vehicle: the evolution of syntax in birdsong and human language through sexual selection. In A. Wray (Ed.), The transition to language (pp. 46-64). Oxford University Press.

Palagi, E., Bertini, M., Annicchiarico, G., \& Cordoni, G. (2020). Mirror replication of sexual facial expressions increases the success of sexual contacts in bonobos. Scientific reports, 10 , 18979. https://doi.org/10.1038/s41598-020-75790-3

Parker, A. R. (2006). Evolving the narrow language faculty: was recursion the pivotal step? In A. Cangelosi, A. D. M. Smith \& K. Smith (Eds.), The evolution of language (pp. 239-246). World Scientific. https://doi.org/10.1142/97898127742620031

Pinker, S., \& Bloom, P. (1990). Natural language and natural selection. Behavioral and Brain Sciences, 13(4), 707-784. https:// doi.org/10.1017/S0140525X00081061

Pinker, S. (2003). The language instinct: How the mind creates language. Penguin Books.

Pfeiffer, J. E. (1982). The creative explosion: An inquiry into the origins of art and religion. Harper \& Row.

Roebroeks, W., \& Villa, P. (2011). On the earliest evidence for habitual use of fire in Europe. PNAS, 108(13), 5209-5214. https://doi.org/10.1073/pnas.1018116108

Simon, H. A. (1969). The sciences of the artificial, $3^{\text {rd }}$ Ed. MIT Press.

Sommer, V., \& Vasey, P. L. (Eds.). (2006). Homosexual behavior in animals: An evolutionary perspective. Cambridge University Press.

Strachey, J. (1953). The Standard edition of the complete psychological works of Sigmund Freud, Volume VII (1901-1905): A case of bysteria, Three Essays on Sexuality and Other Works. I-VI. The Hogarth Press and the Institute of Psychoanalysis.

Strachey, J. (1963). The standard edition of the complete psychological works of Sigmund Freud, Volume XVI (1916-1917): Introductory lectures on psycho-analysis (Part III). I-VI. The Hogarth Press and the Institute of Psycho-Analysis.

Şeker, E. (2017). Sex of the words: A psychoanalytic approach to grammar. International Journal of Language Academy, 5/6, 173187. https://doi.org/10.18033/iila.3742

Tallerman, M. (2008). Holophrastic protolanguage: Planning, processing, storage, and retrieval. Interaction Studies, 9(1), 8499. https://doi.org/10.1075/is.9.1.07tal

Tallerman, M. (2011). Protolanguage. In K. R. Gibson \& M. Tallerman (Eds.), The Oxford handbook of language evolution (pp. 479-491). Oxford University Press. https://doi.org/10.1093/ oxfordhb/9780199541119.013.0051

Tallerman, M. (2014). No syntax saltation in language evolution. Language Sciences, 46(Part B), 207-219. https://doi. org/10.1016/i.langsci.2014.08.002

Tattersall, I. (2014). An evolutionary context for the emergence of language. Language Sciences, 46(Part B), 199-206. https://doi. org/10.1016/i.langsci.2014.06.011

Taylor, T. (1996). The prebistory of sex: Four million years of buman 
sexual culture. Bantam.

Tooby, J., \& Cosmides, L. (1992). The psychological foundations of culture. In J. H. Barkow, L. Cosmides \& J. Tooby (Eds.), The adapted mind: Evolutionary psychology and the generation of culture (pp. 19-136). The Oxford University Press.

Tse, P. U. (2008). Symbolic thought and the evolution of human morality. In W. Sinnott-Armstrong (Ed.), Moral psychology, Volume 1, The evolution of morality: Adaptations and innateness (pp. 269-297). The MIT Press.

Tuttle, R. H. (1981). Evolution of hominid bipedalism and prehensile capabilities. Philosophical Transactions of the Royal Society B, Biological Sciences, 292(1057), 89-94. https://doi. org $/ 10.1098 /$ rstb.1981.0016

Wacewicz, S., \& Żywiczyński, P. (2012). Beyond protolanguage: Contemporary problems in the evolution of language. Theoria et Historia Scientiarum, 9, 5-12. https://doi.org/10.12775/ v10235-011-0001-6

Whiten, A., \& Byrne, R. W. (1988). The Machiavellian intelligence hypotheses: Editorial. In R. W. Byrne \& A. Whiten (Eds.), Machiavellian intelligence: Social expertise and the evolution of intellect in monkeys, apes, and humans (p. 1-9). Clarendon Press/ Oxford University Press.

Wildlife Conservation Society. (2008, February 13). Unique mating photos of wild gorillas face to face. ScienceDaily. www. sciencedaily.com/releases/2008/02/080212134818.htm

Wray, A. (1998). Protolanguage as a holistic system for social interaction. Language \& Communication, 18(1), 47-67. https:// doi.org/10.1016/S0271-5309(97)00033-5

Zywiczynski, P., Gontier, N., \& Wacewicz, S. (2017). The evolution of (proto-) language: Focus on mechanisms. Language Sciences, 63,1-11. https://doi.org/10.1016/j.langsci.2017.06.004

\section{(c) (1) (8) \\ BY NC 2021. Author(s)}

This work is an open access article published under Creative Commons AttributionNonCommercial (CC BY-NC 4.0) license. 